\title{
SUSTAINABLE LIFEWAYS: CULTURAL PERSISTENCE IN AN EVER-CHANGING ENVIRONMENT
}


Penn Museum International Research Conferences

Holly Pittman, Series Editor, Conference Publications

Volume 3: Proceedings of "Forces of Nature:

Risk and Resilience as Factors of Long-term Cultural Change," Philadelphia, January 29-February 3, 2008

\section{PMIRC volumes}

1. Landscapes of Movement. Trails, Paths, and Roads in Anthropological Perspective, edited by James E. Snead,

Clark L. Erickson, and J. Andrew Darling, 2009

2. Mapping Mongolia: Situating Mongolia in the World from

Geologic Time to the Present, edited by Paula L.W. Sabloff, 2011 


\title{
SUSTAINABLE LIFEWAYS
}

Cultural Persistence in an Ever-changing Environment

\author{
EDITED BY
}

Naomi F. Miller, Katherine M. Moore, and Kathleen Ryan 


\section{Library of Congress Cataloging-in-Publication Data}

Sustainable lifeways : cultural persistence in an ever-changing environment / edited by Naomi F. Miller, Katherine M. Moore, and Kathleen Ryan.

p. cm. - (Penn Museum international research conferences v.3)

"Proceedings of "Forces of Nature: Risk and Resilience as Factors

of Long-term Cultural Change,” Philadelphia, January 29-February 3, 2008.”

ISBN-13: 978-1-934536-19-3 (hardcover : alk. paper)

ISBN-10: 1-934536-19-9 (hardcover : alk. paper)

1. Sustainable living-Cross-cultural studies-Congresses. I. Miller, Naomi Frances.

II. Moore, Katherine M. III. Ryan, Kathleen.

GF78.S87 2011

$333.72-\mathrm{dc} 22$

2010049978

(C) 2011 by University of Pennsylvania Museum of Archaeology and Anthropology

3260 South Street, Philadelphia, PA 19104-6324

All rights reserved. Published 2011

Published for the University of Pennsylvania Museum of Archaeology and Anthropology by the University of Pennsylvania Press.

This book was printed in the United States of America on acid-free paper. 